\title{
Comparative study on the potential of agritourism in two Brazilian municipalities ${ }^{1}$
}

\author{
Estudio comparativo de la utilización del potencial agroturístico \\ en dos municipios brasileños
}

\author{
Bernadete da Conceição Carvalho Gomes Pedreira² ${ }^{2}$ (D) \\ Elaine Cristina Cardoso Fidalgo ${ }^{3}$ (D)
}

\begin{abstract}
The knowledge acquired by studying different aspects that can influence agritourism provide for adequate guidelines to carry out this rural activity, leading to greater sustainability and higher chances of success. This study was developed to identify the more important aspects that can improve or limit agritourism and, accordingly, analyse the potential and the limitations for agritourism development in two municipalities of Southeast Brazil. The municipalities are Venda Nova do Imigrante in the state of Espírito Santo, where the agritourism is successfully consolidated and Cachoeiras de Macacu in Rio de Janeiro state, where it is not very significant. This comparison was based on secondary and primary data - the latter were collected during field trips in these municipalities and by getting in touch with representatives of institutions and other local stakeholders. The results showed that the main similarities between the municipalities, which promote agritourism, are environmental, historic and cultural aspects; the presence of family farming with diversified production; and small rural industries. The main differences are the aspects related to land use, tourism management and agritourism infrastructure. An aspect that limits the activity in both municipalities is the lack of specific norms and legislation to guide and organize agritourism.
\end{abstract}

Keywords: Sustainable rural tourism; potential aspects to improve agritourism; tourism management; small family farming.

\section{Resumen}

El conocimiento generado por el estudio de los diferentes aspectos que influyen en el agroturismo ofrece apoyo a la orientación adecuada para la ejecución de esta actividad rural de forma sostenible y con mayor éxito. Esta investigación fue desarrollada con el objetivo de identificar los aspectos más importantes que pueden mejorar o limitar el agroturismo y, a partir de ellos, analizar las potencialidades y limitaciones del desarrollo agroturístico de dos municipios del Sudeste brasileño. Los municipios son Venda Nova do Imigrante, en el estado de Espírito Santo, donde el agroturismo se consolida con éxito, y Cachoeiras de Macacu, estado de Rio de Janeiro, donde es poco significativo. Esta comparación se basa en datos secundarios y primarios recogidos durante las visitas en estos municipios y en los contactos con los

1 This article refers to the final results of the project: "Feasibility study of agritourism derived from family farming in Cachoeiras de Macacu, RJ". (Keywords: rural tourism, planning, environmental conservation), co-financed by The Brazilian Agricultural Research Corporation (Embrapa) and by the National Council of Scientific and Technological Development (CNPq) and executed under the coordination of researcher Bernadete da Conceição Carvalho Gomes Pedreira.

2 The Brazilian Agricultural Research Corporation / Embrapa Soils, Brazil. bernadete.pedreira@embrapa.br

3 The Brazilian Agricultural Research Corporation / Embrapa Soils, Brazil. elaine.fidalgo@embrapa.br 
representantes de instituciones públicas y otras partes interesadas locales. Los resultados mostraron que las principales similitudes entre los municipios que favorecen la actividad recayeron sobre los aspectos de medio ambiente e histórico-cultural, la producción agrícola diversificada de la agricultura familiar y las pequeñas empresas agrícolas. Las principales diferencias entre ellos están relacionadas con el uso de la tierra, la gestión del turismo y la infraestructura dedicada al agroturismo. Un factor limitante común fue la falta de normas y leyes específicas para guiar y organizar la actividad agroturística.

Palabras clave: Turismo rural sostenible; aspectos potenciales para mejorar el agroturismo; gestión del turismo; agricultura familiar.

\section{Introduction}

Although the concepts which define types of tourism in rural environment are broad and often overlap, this study considered the agritourism activity in the rural tourism context, which is more comprehensive and encompasses various types of tourism (Sznajder, Przezborska \& Scrimgeour, 2009). According to Rodrigues (2000), rural tourism must be linked to the intrinsic characteristics of the rural environment, landscape, lifestyle and culture, and exclude activities that do not fit the rural context.

In addition to the main rural tourism features, agritourism is characterized by the direct contact between producers and consumers. Considering the concept of agritourism adopted by Associazione Italiana per l'Agricoltura Biologica [AIAB], (2000), the activity's main characteristics include the producers' hospitality as they use their lands in an integrated and complementary way to agricultural, forestry and livestock production. The latter remain the producers' main sources of income.

Rural tourism in its several versions, and especially agritourism, began to receive world-wide publicity in the 1960s (Portuguez, 2002). Italy was one of the first countries to develop it. According to Tulik (2003), in addition to the essential characteristics of agritourism, in Italy this activity also includes natural landscape, historical and architectural heritage, regional cuisine, local sports and culture.

Rural tourism began in Brazil influenced by the European experience, and according to Lima \& Matias (1999), first started around 1986 in the municipality of Lages, SC. Nowadays, the most representative areas of the activity in Brazil are in the states of Santa Catarina, São Paulo and Espírito Santo (Rejowski, 1999), with characteristics adapted to local and regional specificities (Tulik, 2003).

We stress that there are differences between the rural tourism practiced in countries such as Spain, Portugal, France and Italy and those of Brazil, due to their unique characteristics of geomorphology, natural resources, and diversity of culture and productive activities, comprising the different Brazilian rural scenarios, which has made Brazil adopt a unique model.

Despite rural tourism does not necessarily encompass agricultural activity (including livestock), in Brazil this activity is a main feature in this type of tourism, overlapping other rural characteristics. Even though in some cases agricultural products are limited to a small scale, there is a presence of agricultural production in rural tourism through social and labor practices, artcraft, lifestyle, customs and traditions, which are considered typical of each rural population (Ministério do Turismo, 2004, 2010).

Nowadays in Brazil there is an increasing demand for the several types of tourism in rural areas, especially agritourism. This kind of tourism has been gaining momentum as a means of promoting rural development, raising the income of small rural producers and promoting the conservation of natural, cultural and landscape resources. This contributes to the reduction of the negative effects of land overuse for production and income generation. A positive characteristic of agritourism which stands out in comparison with other types of rural tourism is the customized treatment the activity offers tourists. This treatment requires small-scale planning and performance in order to integrate with the other economic activities developed on site (Campanhola, 2001).

Some publications mention that one of the main factors that make rural tourism attractive in its different types is the natural scenery, with the surrounding topography, vegetation, water resources and favorable weather. Also a tourist site benefits from the attractive conditions of its surroundings (Sznajder, et al., 2009; Ministério do Turismo, 2010).

We highlight that even in lands with the potential for agritourism, there may be legal or natural restrictions aimed at environmental conservation that impairs full use of these lands. 
Thus, it is important to formulate norms, laws and public policies aimed at rural tourism, including agritourism, and that value environmental conservation and other aspects of interest to the activity. Aspects of legislation and norms related to rural tourism in Brazil are presented in a publication of the Inter-American Institute for Cooperation on Agriculture [IICA], (2009).

According to Wilkinson, Camphora, Pinheiro \& Ranauro (2011), the maintenance of the rural landscape coupled with artcraft production and ecosystem services expand the economic dimension of rural environment. This expansion emphasizes not only the social functions attributed to agriculture and agricultural goods, but also reinforces the rural families' commitment to preserve nature, mainly biodiversity and water. On the other hand, to maintain authenticity and local cultural values, and avoid mass tourism, the initiative to develop agritourism must come from rural producers and their communities, and not from external interests (Campanhola, 2001).

As stated above, agritourism complements agricultural production activities carried out in rural areas, and studies of feasibility and planning are required to develop it under sustainable socioeconomic and environmental conditions. In this context we stress the importance to assess local and surrounding conditions and to plan the activity.

Figure 1. Study area

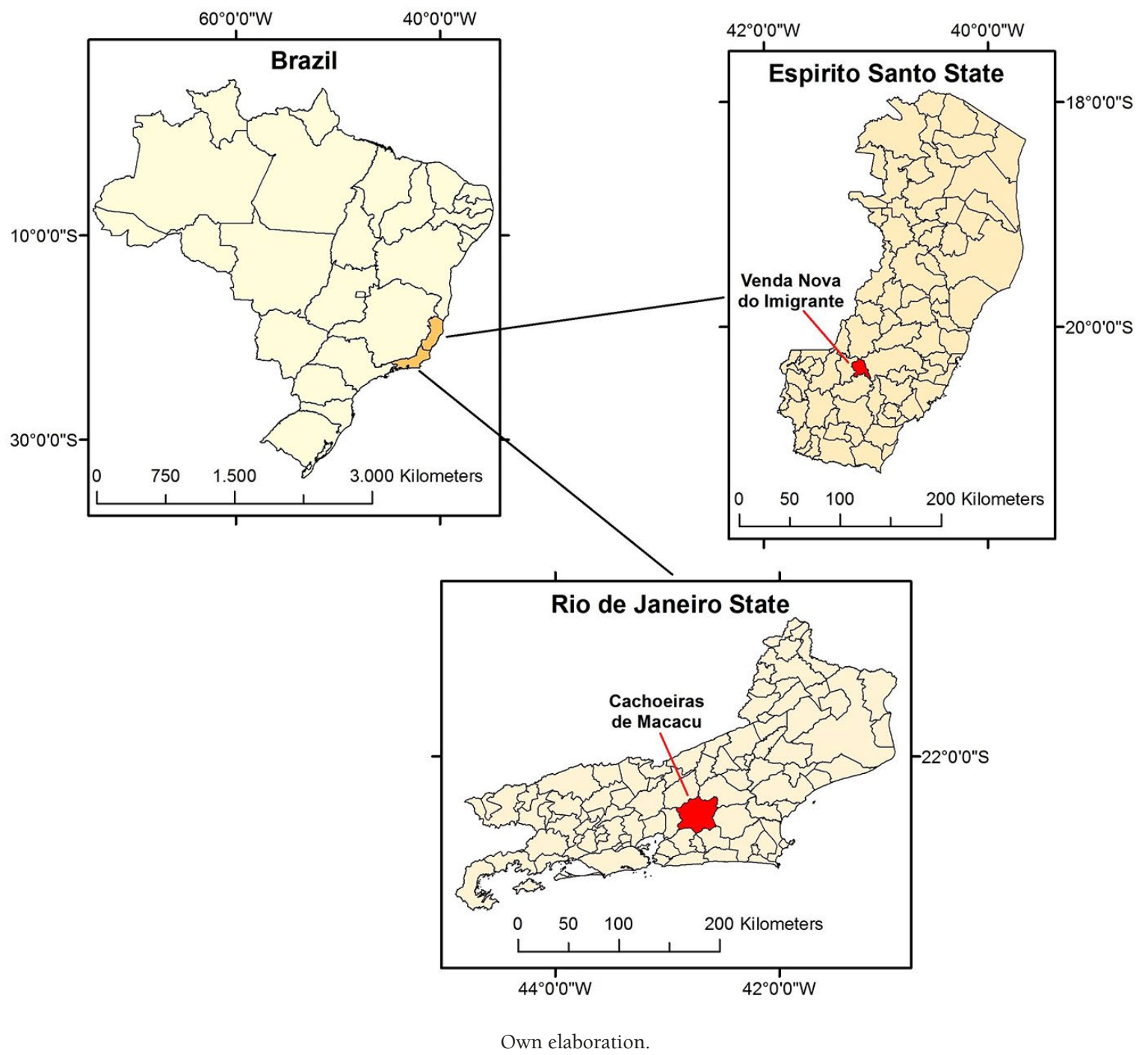

Agritourism involves multidisciplinary interactions. It demands the integration of several factors or aspects so that successful and sustainable development is achieved. Agritourism viability should consider 
at least the aspects associated with environmental and socioeconomic conditions; rural productive activities; and tourist, historical and cultural attributes of the municipality. Tourism management and planning is another relevant aspect to be considered to produce successful initiatives to implement agritourism. (AIAB, 2000; Lacche, 2000; Toresan, Mattei \& Guzzatti, 2002; Sznajder, et al., 2009; Pedreira, Santos \& Pocidonio, 2013).

Even if a region does have the potential to develop agritourism, its characteristics and available resources can influence the success of its implementation and the activity's sustainability. In this context, some important questions are: what aspects can make a rural area effectively feasible to undertake agritourism? What conditions can influence the success of the implementation and maintenance of the activity, considering the environment, socio-economic aspects; land use and agricultural production; presence of rural industries and other rural businesses; tourism infrastructure; historical and cultural attractions; and tourism management and planning?

Considering these questions, this study aimed identifying the more important conditions, or aspects, that can improve or limit agritourism and, based on them, analyzing the potentialities and limitations for the development of this activity in two municipalities of Brazil's Southeast.

One municipality is Venda Nova do Imigrante in Espírito Santo state, known as the "National Capital of Tourism", where the activity is successfully consolidated, and the other is Cachoeiras de Macacu, in Rio de Janeiro state, where agritourism has not been greatly developed (Figure 1).

Venda Nova do Imigrante, with an area of $188.9 \mathrm{~km}^{2}$, is located in the "Central Serrana" region of Espírito Santo state, in the tourist hill region of the state, $103 \mathrm{~km}$ from the state capital, Vitoria. There are two districts and 19 main rural communities spread across two zones: one where there are small farms with olericulture production and the other where Arabic coffee is produced (Pedreira, Fidalgo, Jesus, Pocidonio \& Carneiro, 2012).

Cachoeiras de Macacu is in the eastern Baía da Guanabara region of Rio de Janeiro, in the Macacu river watershed. It is part of Rio de Janeiro's tourist route called Serra Verde Imperial region along with nine other municipalities. It is comprised of three districts with several rural communities in a total area of 955.8 km², 97 kilometers from the state capital (Pedreira, Fidalgo, Araújo, Jesus \& Pocidonio, $2014 \mathrm{a}$ ).

This study highlights similarities and differences between both municipalities and presents information that shows how the municipalities make use of their potentials and available resources. Also we sought to show how they have overcome their existing limitations which interfere in the development of agritourism.

We expect the results will support agritourism planning in areas with potential to develop the activity.

\section{Method}

The survey was developed in three steps: first, a bibliographic survey from technical-scientific literature was carried out to identify the aspects that influence the agritourism; second, primary and secondary data were collected to characterize the potentialities and limitations for agritourism development in Venda Nova do Imigrante and Cachoeiras de Macacu municipalities; and third, a comparative analysis for both municipalities was carried out, considering the identified aspects.

The aspects that influence agritourism and should be considered to compare both municipalities were gathered in a bibliographic survey (AIAB, 2000; Lacche, 2000; Toresan et al., 2002; Tulik, 2003; Complexo Petroquímico do Rio de Janeiro [COMPERJ], 2011; Serviço Brasileiro de Apoio às Micro e Pequenas Empresas-Rio de Janeiro [SEBRAE-RJ], 2011; Szmulewicz, Gutiérrez \& Winkler, 2012; Moraes, Ribeiro \& Emmendoerfer, 2013, Aranha \& Guerra, 2014; Rincón, Santos \& Villegas, 2015).

This bibliographical survey made it possible to select the aspects that influence agritourism and should be used to compare both municipalities: environment; socioeconomics; land use and agriculture production; presence of rural industries and other rural businesses; tourist infrastructure; historical and cultural attractions; and tourism management and planning.

Secondary data from technical-scientific literature and primary data surveyed during field visits were collected in both municipalities to characterize the potentialities and limitations for agritourism, considering the set of aspects selected in the first step. 
Data on environmental and socioeconomic aspects were gathered from secondary sources for both municipalities, and these data are mentioned throughout this text.

Primary data were collected in the local, in field visits and from direct contact with stakeholders aiming at characterizing both municipalities on social organization, land use, agricultural production, the presence of industries and other rural businesses, tourist infrastructure, tourist products, and tourism management.

Due to the fact that Venda Nova do Imigrante had already been developing agritourism, the survey began in this municipality to know the characteristics of local agritourism in order to guide the survey carried out in the municipality of Cachoeiras de Macacu.

In Venda Nova do Imigrante, primary data were collected in July, 2012, without interview schedules. Seven of the 50 agritourism circuit businesses were visited. Other institutions linked to the local agritourism were visited, where 21 people were interviewed: Ministry of Agriculture, Livestock and Food Supply [MAPA]; Institute for Research, Technical Assistance and Rural Extension of Espírito Santo [INCAPER]; Municipal Department of Tourism, Sport and Leisure; Municipal Department of Agriculture, Supply, Livestock, Aquaculture and Fisheries; Brazilian Micro and Small Business Support Service-ES [SEBRAE-ES]; and Coffee Growers Cooperative of Espírito Santo Mountains [PRONOVA]. The detailed data surveyed are published in Pedreira, et al. (2012).

In Cachoeiras de Macacu, primary data were collected from 2012 to 2014 in field visits. Five institutions were visited and contacted their representatives (eighteen people) to collect data. The institutions were: Municipal Department of Tourism, Environment and Urbanism and its Macatur Foundation (six people); Municipal Department of Agriculture, Fisheries, Supply and Regional Development (three people); Municipal Department of Environment (two people); Technical Assistance and Rural Extension Agency of Rio de Janeiro [EMATER-Rio] (six people); and Rio de Janeiro Micro and Small Business Support Service [SEBRAE-RJ] (one person).

Data were collected from some socioeconomic sectors and local family farmers (four interview schedule). They were the only groups for which we applied the interview schedules: most of the local lodgings and hotels (41 interviews), associations (four interviews), cooperatives (two interviews), unions (three interviews), small rural industries and other rural businesses (17 interviews), horse farms and farms with fish farming (four interviews), small family farms indicated by EMATER-Rio of Cachoeiras de Macacu (15 interviews).

The interviews were applied to 86 people and the questions of the interview schedules were selected considering the aspects related to agritourism: presence of natural attractive; perception of environmental impacts on rural farm and their surroundings; organization of rural producers; type of labor, demand, supply and training to develop tourism; source of economic resources and financing; sales of products, consumer markets and distribution; agricultural and forestry activities and their products; infrastructure of rural properties or other businesses for visitation and lodging; historical and cultural heritage in rural farm and surroundings; leisure and recreation options; lodging and hotels; provision of services; availability of norms, laws and public policies; and the way agritourism planning, management and dissemination were done.

The survey of primary data to characterize the municipality in relation to agritourism used data from more than 100 people contacted.

The primary and secondary data collected, the interview schedules, and the results of this survey for Cachoeiras de Macacu are available in Pedreira et al., (2014b).

The environmental aspects considered in this study cover a range of natural elements including vegetation, water resources, geomorphology and topography forms, the composition of these elements in the landscape and the climate. Such aspects can benefit agritourism, since they provide the conditions for tourist visitation, entertainment, leisure, recreation, contemplation and rest in rural areas (Boullón, 1999; Sznajder, et al., 2009; COMPERJ, 2011; Aranha \& Guerra, 2014).

The importance of environmental aspects was highlighted by Lupi, Giaccio, Mastronardi, Giannelli \& Scardera (2017) using a sample of about 11,000 farms from the Italian Farm Accountancy Data Network [FADN] dataset. The results of this survey showed that landscape and environmental variables were 
related to agritourism activities: farms located in protected areas were associated to a higher probability of developing agritourism than farms outside these areas. Additionally, agritourism was associated with a higher incidence of woodlands, natural and semi-natural areas in the farming systems. Another aspect pointed out was that farms located in the higher areas (from seaside hills to mountain) presented a greater chance of carrying out agritourism with respect to farms located in the plain, showing the importance of topography aspects.

Vegetation cover expresses the environmental conditions (Gómez Orea, 1994) and also the attractiveness to rural tourism. Variations in vegetation cover and natural landscape conditions may influence the supply and planning of agritourism and leisure activities.

The characteristics of geomorphology and topography forms can also become landscape attractions as they provide scenic beauty. On the other hand, such characteristics should be taken into account to plan the activities. Santos (2004) emphasizes that geological and soil data integrated with those of topography enable the evaluation of the types of terrain, their natural limitations and potential, as well as the consequences of human intervention.

Water resources, in addition to their importance in terms of quality and quantity for the maintenance of ecosystems and the development of any human activity, are also important to agritourism because of the landscape aspect and the possibilities of entertainment. Pedreira, et al. (2013) emphasizes that areas with greater water density, due to their proximity to water courses, often support the development of leisure and tourism activities and are necessary and important to several agritouristic types of entertainment.

Climate is crucial to tourism planning and all-important to draw up the schedule for tourist attractions throughout the year (Boullón, 1999). Climate characteristics that promote agritourism are those which allow outdoor activities along the year.

The socioeconomic aspects to consider are based on general characteristics, mainly characteristics of population, and the social organization for agritourism. Regarding social organization, it is important to consider that the success of rural tourism and agritourism projects demands participation of rural producers to create a more expressive and diversified supply, and therefore, to motivate tourist visitation (Szmulewicz, et al., 2012). And, according to Gerlach, Batalha \& Mendonça (2010), in agritourism, the joint participation of small groups of producers who use common practices and guide their services to the market, makes it viable to develop the activities on farms, meet quality demands and offer products and services at reasonable costs.

Experiences of agritourism supported by the organization of stakeholders were reported for some regions of Brazil. In the Serra Geral Slopes, in state of Santa Catarina, Guzzatti (2003) reported the history of farmers' organization in the region and their role in agritourism development. The preliminary situation of low social and economic dynamics, with the municipalities isolated and without alternatives, changed with the farmers' organization, which allowed to guide the production and to create small rural industries. After some time, a credit cooperative and a development forum were created to improve the local development. The Coffee Valley Regional Council, which integrated several municipalities in the state of Rio de Janeiro, is another example of organization that benefited agritourism. It acted as an interlocutor and forum to discuss problems, solutions and new perspectives. There were partnerships between entrepreneurs and public institutions that supported the development of products and projects, the promotion and marketing of products, and the provision of infrastructure necessary for the development of local tourism (Ministério doTurismo, 2010).

The other aspects are land use and agriculture production. The agricultural activity (including livestock) is a basic requirement for agritourism (AIAB, 2000; Tulik, 2003). But, the potential for its development depends on the activity's characteristics. Some features favor agritourism, for example, the land ownership structure consisting of small units of family farming production, diversified agricultural and livestock activities, forestry, and the presence of rural businesses (SEBRAE-RJ, 2011).

Small family farming is considered the set of economic activities in rural areas that meet some basic requirements, such as: farms no larger than four modules (minimum reference width of farms in Brazil), the family itself must provide the labor for the economic activities, and most of the family's income must come from agricultural activities developed on the farm (Lei n. 11.326/2006).

Lupi, et al. (2017) highlighted the importance of the presence of small farms and the diversity of products for the development of agritourism in Italy. They noted that agritourism was characterized by 
a landscape mosaic with the minor presence of monoculture production, probably due to the tourist demand for a greater variety of products. Besides this, smaller farms presented a greater probability of practicing agritourism activities. Calatrava (2009) pointed out the importance of the diversified supply of products and services for the development of rural tourism.

Some non-agricultural rural activities connected to rural tourism are integrated to agriculture and livestock, such as rural industries and other rural businesses, which can contribute to agritourism. Tourist interest lies in rural industry products and the production process, which can also become an attraction for visitation (Andrade, 2007; Instituto Capixaba de Pesquisa, Assistência Técnica e Extensão Rural [INCAPER], 2010a). The artcraft, industrial or agricultural production presents natural and cultural characteristics of a region, which can add value to tourist products. In addition, the structuring of productive units qualified and related to tourism gives tourist destinations a competitive advantage (Stange, et al., 2005).

Regarding tourist infrastructure, it is important to map the places where hotels and lodgings are concentrated to enable the proposition and planning of local tourist activities. Another relevant factor is the quality of the hotel and lodging sector's services. In addition to the infrastructure, it is important to consider the availability of basic services visitors can use, such as post offices, garages, gas stations, drugstores, medical care, etc. Other essential factors are the good conditions to access the rural areas of the municipality, and traffic and tourist signs (Boullón, 1994; Dale, 2001; Tulik, 2003).

The tourist attractions comprised of the natural, historical and cultural attributes can also draw interest and/or become complementary elements to agritouristic visitation. These attractions represent even more leisure, contemplation and entertainment options for agritourists. Additionally, the reception of tourists and the management of rural businesses at family level are characteristics that give agritourism an edge as tourists enjoy a more welcoming attraction (Lacche, 2000; AIAB, 2000; Toresan et al., 2002; Tulik, 2003).

The availability of resources and potential for rural tourism is not enough to guarantee the success of the activity. Planning is needed to match this potential to the demands of tourism (Pulido \& Cárdenas, 2011).The development of agritourism requires much interaction among small family farmers and public management (Rodrigues, 2001). In addition to local planning, it is essential to plan the development of tourism at regional and national levels, a process that requires the participation of different levels of society: public power, businessmen, tourism professionals and the community (Martins, Pasquali \& Ribeiro, 2010). It is important that the municipal management be engaged in regional and national policies for tourism development, thus decentralizing tourism management and fostering the activity based on economic, social, cultural, environmental and political sustainability (Salles, 2003).

Other important aspects besides these mentioned were surveyed but the data collected were not enough to make a comparative analysis. For example, the impacts of human activities on land use and the increase in the number of people due to agritourism activities, as well as the actions planned and implemented for its control. Likewise, there was not enough information to analyze the supply of support and training in technical, managerial, administrative, legal, financial and market areas for those involved in agritourism.

In the final step, we compared both municipalities' ability to integrate their existing tourist potential with their agricultural vocation. Also their capacity to properly exploit their various possibilities to create tourist attractions in their rural environment was analyzed.

We verified that while there are studies on the importance of each of the aspects for agritourism, we did not find studies that focus on the integration of these aspects. The results obtained here came from the integrated analysis of this set of aspects to identify potentialities and limitations for agritourism.

Next, the contribution of each of these aspects that can influence and promote agritourism in both municipalities is presented in a comparative way.

\section{Results}

The data presented here refer to the survey carried out in the field (primary data) and from secondary sources, being cited in the text only the secondary sources. A synthesis of the results is presented in Table 1 . 
Table 1. Synthesis of the aspects that can influence agritourism in Cachoeiras de Macacu and Venda Nova do Imigrante.

\begin{tabular}{|c|c|c|c|}
\hline $\begin{array}{l}\text { Aspects } \\
\text { analyzed }\end{array}$ & $\begin{array}{l}\text { Similar aspects identified in } \\
\text { both municipalities }\end{array}$ & $\begin{array}{l}\text { Characteristics identified } \\
\text { in Venda Nova do Imigrante }\end{array}$ & $\begin{array}{c}\text { Characteristics identified in Cachoeiras } \\
\text { de Macacu }\end{array}$ \\
\hline $\begin{array}{l}\text { Environ- } \\
\text { mental }\end{array}$ & $\begin{array}{l}\text { Municipalities and surrounding } \\
\text { region have natural } \\
\text { environmental attributes that are } \\
\text { favorable to rural tourism and to } \\
\text { compose agritourism circuits. }\end{array}$ & $\begin{array}{c}\text { Presence of areas of natural } \\
\text { vegetation but not protected } \\
\text { by law. }\end{array}$ & $\begin{array}{c}\text { The territory is covered by natural vegetation } \\
\text { protected by federal, state and municipal laws (called } \\
\text { Conservation Units). The presence of a watershed that } \\
\text { is an important water supplier to urban areas of the } \\
\text { region. }\end{array}$ \\
\hline $\begin{array}{l}\text { Socio- } \\
\text { economic }\end{array}$ & $\begin{array}{l}\text { Presence of associations, } \\
\text { cooperatives and unions of rural } \\
\text { producers. Strong presence of } \\
\text { family farming-based agriculture. }\end{array}$ & $\begin{array}{l}\text { Presence of solidarity of the } \\
\text { local population as well as their } \\
\text { willingness to do pro-community } \\
\text { volunteer work and the strong } \\
\text { partnership found among small } \\
\text { rural producers. Most of the } \\
\text { population is of Italian descent } \\
\text { and they value their historical } \\
\text { and cultural origins inherited } \\
\text { by the first settlers. Social } \\
\text { organization is based on the } \\
\text { association and cooperation } \\
\text { among rural producers, rural } \\
\text { entrepreneurs and the local } \\
\text { community. }\end{array}$ & $\begin{array}{l}\text { Presence of small number of rural producers in } \\
\text { cooperatives and associations, and their actions are } \\
\text { restricted to marketing their products. The rural and } \\
\text { urban population is not widely aware of agritourism } \\
\text { and its potential to develop the municipality. }\end{array}$ \\
\hline $\begin{array}{l}\text { Land } \\
\text { use and } \\
\text { agriculture } \\
\text { production }\end{array}$ & $\begin{array}{c}\text { Both develop distinct agricultural } \\
\text { activities (including livestock) } \\
\text { which greatly support } \\
\text { agritourism. }\end{array}$ & $\begin{array}{l}\text { The agricultural production } \\
\text { is based on coffee of special } \\
\text { quality, marketed as a product } \\
\text { in the local agritourism, besides } \\
\text { the corn and some species } \\
\text { of fruit. Poultry is the main } \\
\text { livestock activity. There are } \\
\text { also dairy cattle in feedlots and } \\
\text { fish farming. Although honey } \\
\text { production and floriculture are } \\
\text { developed in small scale, they } \\
\text { are used for agritourism. }\end{array}$ & $\begin{array}{l}\text { The agricultural production is distributed throughout } \\
\text { the year and it is diversified, mainly consisting of } \\
\text { vegetables and fruits. Extensive cattle farming is } \\
\text { the most expressive livestock activity. There are } \\
\text { also poultry, and fish farming, breeding of horses } \\
\text { and several horse farms with equestrian activities. } \\
\text { Aquaculture is characterized by the production of } \\
\text { juvenile fish, ornamental fish, frogs and alligators. }\end{array}$ \\
\hline $\begin{array}{l}\text { Rural } \\
\text { industries } \\
\text { and other } \\
\text { rural } \\
\text { businesses }\end{array}$ & $\begin{array}{l}\text { Presence of several small and } \\
\text { artcraft rural industries of } \\
\text { agricultural products. }\end{array}$ & $\begin{array}{l}\text { Production of special coffee, milk } \\
\text { and dairy products, sausages, } \\
\text { "socol" (pork product), fruit } \\
\text { sweets and drinks, jellies, honey, } \\
\text { spices, pasta, and corn products. }\end{array}$ & $\begin{array}{l}\text { Production of fish and fish products, frogs, coconut } \\
\text { water, ornamental fish, and grass in addition to } \\
\text { sausages, smoked products, milk and dairy products, } \\
\text { fruit sweets and drinks, with emphasis on banana } \\
\text { and guava. } \\
\text { The small farms and most of the homemade and } \\
\text { artcraft rural industries of the municipality are } \\
\text { not prepared to develop agritourism. To do so, it } \\
\text { is necessary to adapt it in terms of infrastructure, } \\
\text { service, staff training, dissemination of an agritourism } \\
\text { circuit and its integration. }\end{array}$ \\
\hline $\begin{array}{l}\text { Tourist infra- } \\
\text { structure }\end{array}$ & $\begin{array}{l}\text { Presence of equipment and } \\
\text { services for tourism: restaurants, } \\
\text { hotels and lodgings, and leisure } \\
\text { options. Both municipalities } \\
\text { do not present any limitations } \\
\text { related to basic services. }\end{array}$ & $\begin{array}{l}\text { Presence of consolidated and } \\
\text { well signaled agritourism circuits, } \\
\text { receptive welcome given to } \\
\text { visitors by the local population. }\end{array}$ & $\begin{array}{l}\text { Tourist reception and information is poor, as well as } \\
\text { the tourist signs. Lack of qualified and specialized } \\
\text { staff to attend to visitors. Lack of adequate } \\
\text { infrastructure and logistic conditions necessary to } \\
\text { agritourism: power supply and communication in } \\
\text { rural areas, tourist signs, roads and ways, public } \\
\text { transportation (urban, rural and between cities) and } \\
\text { guidance to agritourism, among others. }\end{array}$ \\
\hline $\begin{array}{l}\text { Historical } \\
\text { and cultural } \\
\text { attractions }\end{array}$ & $\begin{array}{l}\text { The historical, cultural and } \\
\text { natural attributes make it } \\
\text { possible to create a diversity of } \\
\text { tourism products besides the } \\
\text { sports and handicraft. Presence } \\
\text { of festivities and events of } \\
\text { interest to the agritourism. }\end{array}$ & $\begin{array}{l}\text { Availability of an annual calendar } \\
\text { of events, a tourist map and } \\
\text { information on accommodation } \\
\text { and food. As a strong element } \\
\text { of tourist attraction, one has the } \\
\text { traditions of the culture of the } \\
\text { European immigrants. } \\
\end{array}$ & $\begin{array}{l}\text { Lack of an annual calendar of events and tourist map. } \\
\text { Lack of visitation itineraries for agritourism. Some } \\
\text { limitations are due to the lack of definition of places } \\
\text { for exhibition and sales of artcraft, agricultural and } \\
\text { derived products, and lack of a local culinary identity. }\end{array}$ \\
\hline $\begin{array}{c}\text { Tourism } \\
\text { management } \\
\text { and } \\
\text { planning }\end{array}$ & $\begin{array}{l}\text { Presence of public institutions } \\
\text { linked to agricultural and rural } \\
\text { tourism activities and existence } \\
\text { of state and municipal programs } \\
\text { to support agricultural activities. } \\
\text { Lack of specific norms and laws } \\
\text { to guide the activity, as well as } \\
\text { to define the rights and duties of } \\
\text { those involved. }\end{array}$ & $\begin{array}{l}\text { There is a group of public } \\
\text { institutions (federal, state and } \\
\text { municipal) whose offices are at } \\
\text { the same site, reinforcing the } \\
\text { integrated work for management } \\
\text { and planning actions. Presence } \\
\text { of a governance agency that } \\
\text { organizes local and regional } \\
\text { tourism and does its promotion. }\end{array}$ & $\begin{array}{l}\text { The limited integration between public institutions, } \\
\text { as well as, rural industries ventures, the hotel and } \\
\text { lodging sector, rural producers and businesses } \\
\text { make it difficult to plan coordinated actions. Lack } \\
\text { of a governance agency to promote tourism like the } \\
\text { Convention Visitors Bureau. }\end{array}$ \\
\hline
\end{tabular}

Own elaboration. 


\subsection{Environmental aspects}

Considering secondary data for Cachoeiras de Macacu (Instituto Bioatlântica [Ibioatlântica], 2009; Instituto Estadual do Ambiente [INEA], 2009; COMPERJ, 2011; Universidade Federal Fluminense [UFF], 2004) and for Venda Nova do Imigrante (INCAPER, 2010b), both municipalities are similar in some environmental aspects. They have environmental resources and the municipalities can benefit from them as these resources can foster agritourism. This advantage comes from the characteristics of their natural landscape, with favorable climate and no major seasonal variations in temperature and rainfall. Other points of interest include good-quality water resources; rich biodiversity; and the scenic beauty provided by the mountains around the cities and the Atlantic Forest natural vegetation covering the territory.

Regarding the climate, the municipalities and the surrounding areas present favorable characteristics to agritourism, as their seasonality does not affect tourism projects.

These surrounding areas also present attractive environmental characteristics, increasing the possibility of interactions with other neighboring tourist cities to comprise agritourism circuits.

The analysis of the differences between the municipalities shows that Cachoeiras de Macacu is rich in good-quality water resources and stands out as a major fresh water producer. It is also an important water supplier to urban areas. In addition, much of its territory is covered by natural vegetation protected by federal, state and municipal laws (called Conservation Units). Although these characteristics are not present in Venda Nova do Imigrante, they do not seem to play a part in the success or failure of the activity.

We stress that the main restrictions to agritourism in both municipalities refer to threats to the protection of water and soil resources due to several factors, including an increase in tourist demand, inappropriate agricultural use and management, erosion and the use of agrochemicals.

\subsection{Socioeconomic aspects}

Both municipalities show a high Human Development Index over 0.7, according to the Atlas of Human Development in Brazil (Programa das Nações Unidas para o Desenvolvimento [PNUD], Instituto de Pesquisa Econômica Aplicada [Ipea] \& Fundação João Pinheiro [FJP], 2013) in the analysis of the general characteristics of health, income and education, without affecting agritourism.

A major advantage found in Venda Nova do Imigrante in comparison with Cachoeiras de Macacu is its social organization based on the cooperation among rural producers, rural entrepreneurs and the local community, which helps agritourism. The professional training and formation of community associations, which were informal and voluntary at first, were key to the success of agritourism in this municipality. Each farm or rural entrepreneur seeks to specialize in different products and services and thus, become complementary; also family farmers involved in agritourism seek to jointly publicize their products.

According to Funcke (2009), there are a small number of producers in cooperatives and associations in Cachoeiras de Macacu, and their actions are restricted to marketing their products. There are few actions to purchase inputs, search for technologies, and professional training. We noted that a significant limitation to local agritourism is the low adherence and poor performance of the producers' social organization aimed at tourism.

Cachoeiras de Macacu has approximately 60,000 inhabitants, mostly in urban areas. The service sector is the most developed and generates the largest number of jobs (Wilkinson, et al., 2011; 2012; SEBRAE-RJ, 2011). Despite its relevant environmental characteristics and strong presence of family farming-based agriculture, where small farms and some settlements predominate, the tourist potential of the rural region associated to agricultural and livestock production is still underexplored. The rural and urban population is not widely aware of agritourism and its potential to develop the municipality. This lack of knowledge seems to result in the local residents' little interest in the activity.

On the other hand, in Venda Nova do Imigrante, where agricultural and agribusiness activities account for a significant portion of the municipal gross domestic product [GDP], there is an effective use of its potential for agritourism. More than 50 farms work with agritourism for both visitation and sale of products from family farming-based agriculture. Its expressive family farming-based agriculture, developed on small farms, creates a favorable scenario to agritourism, generating jobs for the local people to meet the continuous demand for visitation, and thereby strengthening the local economy. 
The population of the municipality is approximately sixty thousand, $60 \%$ of which live in urban areas. Most of the population is of Italian descent and they value their historical and cultural origins inherited by the first settlers. The solidarity of the local population is worth highlighting, as well as their willingness to do pro-community volunteer work and the strong partnership found among small rural producers.

In Venda Nova do Imigrante these characteristics work in favor of agritourism. In this context, an association focused on leveraging this activity was created. The same was not observed in Cachoeiras de Macacu.

\subsection{Aspects of land use and agriculture production}

Considering land ownership structure, the predominant presence of small properties of family farmers favors the development of agritourism in both municipalities studied. Also, both develop distinct agricultural activities (including livestock) which greatly support agritourism.

The production of coffee in Venda Nova do Imigrante stands out for its high quality, and it is marketed as a product of local agritourism. Corn and fruit production is also important. Considering livestock, dairy cattle are raised in feedlots, but poultry is the main activity. There are fisheries and aquaculture, but only for family consumption and tourism. Forestry, represented by the cultivated area of eucalyptus, is expanding slowly. Small-scale flower production is used for agritourism.

Cachoeiras de Macacu presents favorable characteristics for agritourism. The agricultural activities in the municipality are developed in small areas and are well distributed across the territory. There is also a diversity of products, mainly vegetables and fruits, especially guava and bananas; and livestock products, including those from aquaculture. The local calendar shows that production is well distributed throughout the seasons.

The most important livestock activity in Cachoeiras de Macacu is extensive cattle farming. Aquaculture is somewhat expressive, and includes fish farming, production of juvenile fish, ornamental fish, frogs and alligators. Poultry farming is not very expressive. There is horse breeding, several horse farms, and equestrian activities in the municipality. The area of forestry, based on eucalyptus, is slowly expanding. Floriculture is not widespread. Considering livestock activities are naturally attractive for agritourism, although these activities are present in the municipality, this potential has not been used for this purpose. It is important to mention that dams might be built in the rural area of agricultural production of Cachoeiras de Macacu.

This leads to uncertainties that could result in land use changes, and in some way, interfere with the availability of agricultural products and also modify the landscape, affecting agritourism attractiveness.

\subsection{Aspects related to the presence of rural industries and other rural businesses}

There are various small or artcraft rural industries which process agricultural products in Cachoeiras de Macacu, in addition to other agricultural and rural businesses. These businesses produce fish and fish products; frogs; fruit sweets and drinks; milk and dairy products; sausages; smoked products; coconut water; ornamental fish; and grass.

Some offer "catch and pay" fishing. All these businesses can favor agritourism. However, the small farms and most of the homemade and artcraft rural industries of the municipality are not prepared to develop agritourism. To do so, it is necessary to adapt it in terms of infrastructure, service, staff training, dissemination of an agritourism circuit and its integration.

In Venda Nova do Imigrante there are small and artcraft rural industries of agricultural products and agritourism businesses, where different goods are produced and marketed, such as special coffee; milk and dairy products; sausages, with "socol" (pork product) as a highlight; honey; fruit sweets and drinks; spices; pasta; and corn products. All these products are local agritourism attractions.

\subsection{Aspects related to tourist infrastructure}

Cachoeiras de Macacu and its surroundings have a reasonable road infrastructure, but the precarious conditions of the secondary roads may impair tourism. Considering the equipment and services required for tourism, there are hotels and lodgings, but simple installations are predominant. The area lacks qua- 
lified and specialized staff to attend to visitors. Tourist reception and information is poor, as well as the tourist signs.

The so-called "one day tourism" is also common, leading to crowds of tourists in few places. The infrastructure to receive this large number of tourists is precarious causing environmental degradation. There is also an increase in the demand for lodgings and hotels due to the events and various tourist activities related to rural environment that occur in the municipality, but the demand has not been met accordingly.

There are services and equipment for tourism in Venda Nova do Imigrante: several hotels and lodgings and leisure activities, restaurants, typical food, easy access, welcoming reception by the local population. In addition, tourist signs as well as leaflets with information on agritourism are supplied by the producers who participate in the activity. Accessing the sites is easy and the agritourism circuits are well signaled, and there is a tourist map of the municipality available for visitors. The City Hall also provides information on hotels, lodgings and restaurants in an annual calendar of events. The agritouristic circuit in this municipality, with the participation of at least 20 rural properties, is yet another highlight.

Considering the basic services, both municipalities do not present any limitations.

\subsection{Aspects related to historical and cultural attractions}

Considering this aspect, both municipalities have in common the supply of alternatives that serve as entertainment, tourism and leisure. There is also the possibility of interaction with other cities of the region through rural tourism circuits, which favor agritourism initiatives.

Venda Nova do Imigrante has various tourist products of historical and cultural nature as well as cultural events. Among these products, highlights include the artcraft made with dried parts of the coffee plant, sisal and others, and delicacies. A strong element of tourist and cultural attraction is the tradition of the European immigrants' culture, and the promotion of various events such as festivals and folk festivities, mostly associated to agritourism. One of the main attractions is the consolidated agritouristic circuits, which is part of the region's tourist route. The City Hall provides an annual calendar of events with information on all options of leisure, tourism and entertainment. The disclosure of these activities by local media has contributed strongly to the visibility of agritourism, since it began.

Highlighting the importance of circuits, there are other examples of circuits that promoted the agritourism, as the Way of the Rocks (Caminho das Pedras), the Welcome of the Colony (Acolhida da Colonnia) (Turnes \& Guzzati, 2015; Guzzati, Sampaio \& Coriolano, 2013), and Paths of Colony (Caminhos da Colônia) (Tomazzoni, Bock \&Simon, 2012), all them in Southern Brazil.

Cachoeiras de Macacu has historical and cultural attractions among the tourist products promoted through the cultural heritage events, including folk traditions celebrated in festivals and commemorative dates; cultural festivals (dance and music); artcraft fairs; meetings of guitar players; battles of bands and street bands. And there are festivals of agricultural production with sales of local products and animal auction, as well as several horse farms that house different activities. Also there are technical and scientific attractions which stemmed from touristic and entertainment activities that can occur in conservation units, in institutions for education, production and research, e.g. in a riding school and veterinary school farm.

Although there is a great quantity and diversity of attractions and events in Cachoeiras de Macacu's rural area, their use as tourist products is small. Some of the problems lie in the fact that Cachoeiras de Macacu does not have a steady cultural or event calendar. In addition, these attractions and events have not contributed to agritourism. Some limitations are due to the lack of definition of places for exhibition and sales of artcraft, agricultural and derived products; lack of a local culinary identity, and lack of consolidated visitation itineraries for agritourism. According to the Local Agenda 21 Program of Cachoeiras de Macacu (COMPERJ, 2011), as a general evaluation, the use of historical and cultural heritage for tourism still receives little attention from public and private institutions, which could improve the sector's growth.

\subsection{Aspects related to tourism management and planning}

On these aspects, the municipalities hold some similarities and differences which may have an influence on the success of agritourism.

There is a group of public institutions (federal, state and municipal) whose offices are at the same site in Venda Nova do Imigrante. This reinforces the commitment of public power to agritourism. At 
federal level there are the Ministry of Agriculture, Livestock and Food Supply [MAPA] and the Ministry of Agrarian Development [MDA]; at state level, there is the INCAPER; and there is the Department of Agriculture, Supply, Livestock, Aquaculture and Fisheries at municipal level. The interviews carried out in all these institutions showed their relationship with the local agritourism.

INCAPER promotes initiatives to boost rural tourism, such as the preservation of rural landscapes, the recovery of local landscape potential, incentives to improve property appearance and maintenance of rural characteristics. It develops the Program of Technical Assistance and Rural Extension [PROATER] in the municipality which is a management tool and takes on the challenge of contributing with the sustainable development of small family farming. The focus of the technical assistance and rural extension agents is to improve the quality of life of the small family farmers.

In addition to INCAPER, the SEBRAE-ES operates activities which promote agritourism and training in the municipality.

The Department of Agriculture, Supply, Livestock, Aquaculture and Fisheries works along with INCAPER and the Union of Rural Workers of Venda Nova do Imigrante to organize the Small Family Farming Fair. The Department of Tourism, Sports and Leisure acts directly to support rural tourism and agritourism, with various actions to foster the creation, development and dissemination of activities linked to local agritourism, such as tours, exhibitions, fairs, festivals and others. The Municipal Master Plan contributes to plan and manage agritourism as it defines zones with the potential for rural tourism and agritourism - it also establishes guidelines for these activities in the municipality.

The Convention Visitors Bureau is another important element to promote agritourism in Venda Nova do Imigrante. It is a governance agency that organizes local and regional tourist and agritouristic tours, and it is responsible for their dissemination and promotion.

Despite the many favorable conditions, the public and private initiatives of the municipality still need to advance in order to improve conditions to develop agritourism.

Tourism management in Cachoeiras de Macacu has been carried out mainly through initiatives with the direct or indirect participation of local or state public institutions aimed at supporting activities of the agricultural and tourism sector. Other institutions also participate aiming to interact with other social actors such as public managers, several associations, organized groups and the community. Also in this municipality, the interviews carried out in the local institutions allowed to show their relation with the agritourism.

The following public federal programs are present in Cachoeiras de Macacu: the National Program for the Strengthening of Family Farming [PRONAF] which provides funding for individual or collective projects that generate income for family farmers and settlers of the national agrarian reform program: the National School Food Program [PNAE] which calls for part of the resources to be used to purchase food from small family farms and rural family entrepreneurs; and the Rural Tourism in Family Agriculture Program - Rural Tourism Network in Family Agriculture [Rede Traf] which aims to promote sustainable rural development by implementing and strengthening tourism activities integrated with local productive arrangements, improving life conditions by helping to provide income and work. Some small family farmers of Cachoeiras de Macacu participate in these programs.

The state institutions are the most active in the municipality, such as the EMATER-Rio, with a technical staff working at its local office. But, EMATER-Rio has not provided effective actions focused on agritourism with the rural producers of the municipality yet.

Projects for rural tourism initiatives are being developed in the surrounding region of Cachoeiras de Macacu supported by SEBRAE-RJ to assist the development of small tourist businesses by carrying out individual actions and collective projects. But, there are no specific actions aimed at rural tourism in the municipality yet. However, there is a partnership between the Commercial and Business Association of Cachoeiras de Macacu [ACECAM] and SEBRAE-RJ, which, through the Empreender State Program, works to mobilize local entrepreneurs of the hotel and lodging sector to develop it, thus helping agritourism.

Other initiatives: the Prosperar Program created by Rio de Janeiro Government to support family-based rural industries to which many small rural farmers are linked; the Rio de Janeiro State Artcraft Program, which has been developed in partnership with the Rio de Janeiro State Tourism Company [TurisRio] and several other institutions; and the Rio de Janeiro State Sustainable Rural Development Project 
[Rio Rural], which faces the major challenge of improving quality of life in rural areas, supporting the income increase for rural producers as well as the conservation of natural resources.

The Strategic Master Plan of Cachoeiras de Macacu (Lei Municipal n. 1.653/2006) calls for measures to support tourism and local territorial planning, establishing tourist centers and agritourism areas - the master plan has been revised since 2013. Although they are in the municipal planning, these centers and areas have not left the drawing board yet.

The Macatur Foundation, an executive branch of the Department of Tourism, Environment and Urbanism of Cachoeiras de Macacu, works to promote the municipality and its attractions in order to foster tourism mainly based on local natural resources. However, there are no specific initiatives for the development of agritourism. There is also no tourism-oriented instance of governance in the municipality, such as the Convention Visitors Bureau, although attempts have been made to implement it, but without success.

The Municipal Tourism Council is being reactivated, but its activity focused on agritourism is not significant.

The Department of Agriculture, Fisheries, Supply and Regional Development does not include agritourism in its activities with the local producers.

Considering the municipal public programs, we can highlight the Municipal Program of Small Rural Industries Support [Agroindustrializando] and Agenda 21 of Cachoeiras de Macacu, which aims at the sustainable development. This set of public programs in the municipality can contribute to the development of sustainable rural tourism.

Cachoeiras de Macacu presents many characteristics that favor agritourism involving small family farmers and local community. A current positive factor that aids the development of local agritourism is the efforts to enhance tourism management by means of initiatives and direct and indirect contributions. These efforts are put forth by the municipal government (the City Hall and the Department of Tourism) as well as state institutions such as EMATER-Rio and SEBRAE-RJ. However, there are several obstacles, such as those regarding tourism management and planning.

We also stress obstacles that impair adequate infrastructure and logistic conditions necessary to agritourism: power supply and communication in rural areas, tourist signs, roads and ways, public transportation (urban, rural and between cities) and guidance to agritourism, among others.

Another weakness is the limited integration between rural industries ventures, the hotel and lodging sector, rural producers and businesses making it difficult to plan coordinated actions. As pointed out in the Agenda 21 (COMPERJ, 2011), sustainable tourist businesses employ and provide training to the local residents, but locally produced goods and also use local services.

One aspect that limits agritourism is the lack of specific norms and legislation to guide and organize the activity in both municipalities and the surrounding regions, as well as to define the rights and duties of those involved. Also at national level in Brazil there is no specific legislation that regulates agritourism, while in Italy, for example, there is the National Legal Framework for Agritourism, and in Spain, the activity is regulated at the regional level (Streifeneder, 2016).

\section{Discussion}

Although the adopted strategy for data collection was different for each municipality, we could analyze and compare the conditions that can promote agritourism (potentialities and limitations) in these municipalities, since all aspects previously selected were considered in both.

Other studies also considered the same aspects analyzed here to identify their influence on agritourism activity in different regions of Brazil and abroad, reinforcing their relevance.

The results have shown that the existence of rural areas with potential to develop agritourism is a required condition, but does not guarantee the activity will be successful.

In sum, the main characteristics that favor the activity presented by both municipalities are: the natural attributes of the rural landscape; the historical and cultural attractions; the presence of family farming with diversified production; the presence of small or artcraft rural industries; the agritourism infrastructure; and the potential for tourism found in both regions. 
Although these characteristics are common to both municipalities, their use to boost agritourism is different, and so is the effective implantation of the activity.

The differences observed between the municipalities may have led to its success or limited it. Considering Venda Nova do Imigrante, the conditions that favor agritourism are: the capacity of small farmers to associate around agritourism; the specific proposals and strategies to develop agritourism by the municipal and state management which attract other supporting institutions; the presence of a consolidated agritourism circuit part of the region's tourist route; the publicity received by the city and its tourist attractions, as well as the offer of tourist information; and the valorization of the local culture adding to agritourism.

The fact that the rural and urban population is not widely aware of agritourism, showing little interest in the activity, is one aspect that limits its development in Cachoeiras de Macacu. The limited integration between rural industries, the hotel and lodging sector, rural producers and businesses makes it difficult to plan coordinate actions. Although there are some attractions and events in rural area, they have not contributed to the agritourism and its products. The absence of visitation itineraries, a cultural or event calendar, tourist signs, and guidance to agritourism are consequences of lack of planning and organization for this activity.

Aspects that limit the activity in both municipalities are the lack of specific norms and legislation to guide and organize agritourism, and the threats to the environment due to inappropriate management of natural resource use.

The comparative analysis between both municipalities led to the identification of the factors that affect agritourism, yielding benefits or constraints to its development.

\section{Conclusions}

The results of this work allowed to identify important aspects for the development of agritourism in the municipalities of Cachoeiras de Macacu and Venda Nova do Imigrante, Southeastern Brazil. Although the analysis has been restricted to two municipalities, it reflects similar conditions, noticed in several other municipalities in that region.

The surveyed data sources were diverse due to the lack of organized, updated and available data on tourism and, especially on rural tourism and agritourism. The gathered information relied on the search from different sources, actors and institutions, therefore, the data did not come from standardized and continuous records. This fact required an effort both for data collection and for its organization and synthesis.

Although there could be gaps in the results of this study, the gathered information allowed to point out the aspects that can improve or limit agritourism in both municipalities and, based on them, to analyze the potentialities and limitations for the development of the activity.

\section{References}

Andrade,H. K. (2007). Impactos da Aquicultura no Turismo. Vitória:SEBRAE-ES. Retrieved from http://www. bibliotecas.sebrae.com.br/chronus/ARQUIVOS_CHRONUS/bds/bds.nsf/0296D929E95196B083 2573A30048910F/\$File/NT00037326.pdf

Aranha, R. C. \& Guerra, A. J. T. (Org.) (2014). Geografia aplicada ao turismo. São Paulo: Oficina de Textos.

Associazione Italiana per l'Agricoltura Biologica. [AIAB]. (2000). Formazione Eco-Turismo: Progetto Leonardo da Vinci. Retrieved from http://cc.bingj.com/cache.aspx?q=progetto+leonardo+forma zione+ecoturismi+AIAB\&d=4844845089948898\&mkt=pt-BR\&setlang=pt-BR\&w=SyrUasyGqybLiuVImrawRK5Ywh3z_X_

Boullón, R. C. (1994). Planificación del espacio turistico. México, DF: Editorial Trillas.

Boullón, R. C. (1999). Las actividades turísticas y recreacionales: el hombre como protagonista. México, DF: Editorial Trillas.

Calatrava, J. (2009). La multifuncionalidade de la agricultura: implicaciones para el análisis de los sistemas agrarios. In: S. Sayadi \& C. Parra (Eds.). Multifuncionalidad agraria, desarrolho rural y políticas públicas: nuevos desafíos para la agricultura. (Chap. 2, pp. 45-63). Sevilha: Junta de Andalucía. Instituto de Investigación y Formación Agraria y Pesquera Consejería de Agricultura y Pesca. Retrieve 
from http://www.juntadeandalucia.es/export/drupaljda/1337160963Multifuncionalidad_agraria completo.pdf

Campanhola, C. A. (2001). Sustentabilidade do novo rural brasileiro. II Seminário sobre o Novo Rural Brasileiro. Campinas: Instituto de Economia Núcleo de Economia Agrícola/Universidade de Campinas.

Complexo Petroquímico do Rio de Janeiro [COMPERJ]. (2011) Agenda 21 Local de Cachoeiras de Macacu. Rio de Janeiro: Petrobrás, Ministério do Meio Ambiente, Secretaria de Estado do Ambiente (RJ). Retrieved from https://pt.scribd.com/doc/312424558/Agenda-21-Cachoeiras-de-Macacu-pdf

Dale, P. J. (2001). Novas dimensões da ruralidade: turismo e desenvolvimento territorial. (Dissertação de mestrado). Universidade de São Paulo.

Funcke, A. L. (2009). Estudo de Localização do Arranjo Produtivo Local (APL) da Banana como Estratégia de Desenvolvimento Territorial no Estado do Rio de Janeiro. (Dissertação de mestrado). Universidade Federal Rural do Rio de Janeiro.

Gerlach, F. R.; Batalha, M. O.; Mendonça, M. C. A. (2010). Impactos da combinação associativismo e agroturismo sobre o agronegócio: Uma experiência em Venda Nova do Imigrante-ES. Coletânia de Artigos Científicos, 1 (1). Retrieved from https://www.researchgate.net/profile/Mario_Batalha/ publication/268177023_IMPACTOS_DA_COMBINACAO_ASSOCIATIVISMO_E_AGROTURISMO_ SOBRE_O_AGRONEGOCIO_Uma_experiencia_em_Venda_Nova_do_Imigrante_-ES/ links/5471c9890cf2d67fc03453fd/IMPACTOS-DA-COMBINACAO-ASSOCIATIVISMO-EAGROTURISMO-SOBRE-O-AGRONEGOCIO-Uma-experiencia-em-Venda-Nova-do-Imigrante-ES.pdf

Gómez Orea, D. (1994). Ordenación del territorio: una aproximación desde el médio físico. Madrid: Instituto Tecnológico Geominero de España.

Guzzatti, T. C. (2003). O agroturismo como instrumento de desenvolvimento rural: sistematização e análise das estratégias utilizadas para a implantação de um programa de agroturismo nas encostas da serra geral catarinense. (Dissertação de mestrado). Universidade Federal de Santa Catarina. Retrieved from https://repositorio.ufsc.br/bitstream/handle/123456789/86515/224501.pdf? sequence=1

Guzzatti, T. C., Sampaio, C. A. C. \& Coriolano, L. N. M. T. (2013). Turismo de base comunitária em territórios rurais: caso da Associação de Agroturismo Acolhida na Colônia (SC). Revista Brasileira de Ecoturismo. 6 (1), 93-106. Retrieved from http://www.sbecotur.org.br/rbecotur/seer/index.php/ ecoturismo/article/viewFile/609/415

Instituto Bioatlântica [Ibioatlântica]. (2009). Plano de Manejo - APA da bacia do rio Macacu. Rio de Janeiro: Instituto BioAtlântica.

Instituto Capixaba de Pesquisa, Assistência Técnica e Extensão Rural [INCAPER]. (2010a). Incaper: 10 anos de integração pesquisa-extensão. Incaper em Revista. 1(1), 106-109. Retrieved from https:// pt.scribd.com/document/312757157/Incaper-Em-Revista-Volume-1

Instituto Capixaba de Pesquisa, Assistência Técnica e Extensão Rural [INCAPER]. (2010b). Programa de Assistência Técnica e Extensão Rural 2011-2013: Venda Nova do Imigrante. Retrieved from https:// incaper.es.gov.br/media/incaper/proater/municipios/Centro_cerrano/Venda_Nova.pdf

Instituto Estadual do Ambiente [INEA]. (2009). Plano de Manejo do Parque dos Três Picos. Rio de Janeiro: Instituto Estadual do Ambiente. (1 ${ }^{\text {a }}$. revisão). Retrieved from http://200.20.53.3:8081/cs/groups/ public/documents/document/zwew/mde5/ edisp/inea0019756.pdf

Instituto Interamericano de Cooperación para la Agricultura [IICA]. (2009). Diagnóstico de Turismo Rural en el Brasil: un concepto en construcción. Retrieved from http://repiica.iica.int/docs/b3708e/b3708e.pdf

Lacche, F. (2000). Guida Agli Agriturism Bioecologici. Le Guide di Natura \& Salute. Bolonha: Tecniche Nuove.

Lei n. 11.326/2006. (2006). Estabelece as diretrizes para a formulação da Política Nacional da Agricultura Familiar e Empreendimentos Familiares Rurais. Retrieved from http://www.planalto.gov.br/ccivil_03/ Ato2004-2006/2006/Lei/L11326.htm

Lei Municipal n. 1.653/2006. (2006). Dispõe sobre o Plano Diretor Estratégico do Município de Cachoeiras de Macacu. Cachoeiras de Macacu. Retrieved from http://www.cachoeirasdemacacu.rj.gov.br/DO/ lei_1653_parte_01.pdf 
Lima, I.M.A. \& Matias, M. (1999). A cultura no contexto do turismo no espaço rural brasileiro. In C. G. S. Oliveira (Ed.), Anais do I Congresso Brasileiro de Turismo Rural: turismo no espaço rural brasileiro. (pp. 99-112). Piracicaba: FEALQ.

Lupi, C.; Giaccio, V., Mastronardi, L., Gianelli, A \& Scardera, A. (2017). Exploring the features of agritourism and its contribution to rural development in Italy. Land Use Policy. 64, 383-390. https:// doi.org/10.1016/j.landusepol.2017.03.002

Martins, D. F. Q., Pasquali, R. \& Ribeiro, A. L. R. (2010). Planejamento do turismo rural na região de Cáceres, MT. In Anais do VII Congresso Brasileiro de Turismo Rural: o turismo rural e as territorialidades na perspectiva do campo e da cidade, Presidente Prudente.

Ministério do Turismo. (2004). Diretrizes para o desenvolvimento do turismo rural: Brasil. Brasil. Brasília, DF: Ministério do Turismo. Retrieved from http://www.turismo.gov.br/sites/default/turismo/o_ministerio/ publicacoes/downloads_publicacoes/Diretrizes_Desenvolvimento_Turismo_Rural.pdf

Ministério do Turismo. (2010). Turismo rural: orientações básicas. Brasília, DF: Ministério do Turismo. Retrieved from http://www.turismo.gov.br/sites/default/turismo/o_ministerio/publicacoes/downloads publicacoes/Turismo_Rural_Versxo_Final_IMPRESSxO_.pdf

Moraes, W. V., Ribeiro, G. A. \& Emmendoerfer, M. L. (2013) Ensaio de uma metodologia com indicadores para o turismo de base comunitária: o caso do Território da Serra do Brigadeiro - Brasil. Revista de Turismo y Patrimonio Cultural, 11(2), 297-312. https://doi.org/10.25145/j.pasos.2013.11.019

Pedreira, B. C. C. G., Fidalgo, E. C. C., Jesus, I. R. D., Pocidonio, E.A.L., \& Carneiro, M. J. T. (2012). Aspectos do agroturismo desenvolvido em Venda Nova do Imigrante (ES) em subsídio ao levantamento do potencial agroturístico de Cachoeiras de Macacu (RJ). Documentos, (147). Retrieved from https:// ainfo.cnptia.embrapa.br/digital/bitstream/item/104935/1/DOC-147-Aspectos-Agroturismo.pdf

Pedreira, B.C.C.G., Santos, R.F., \& Pocidonio, E.A.L. (2013). Indicadores para selecionar áreas agroturísticas: o desempenho dos atributos agropecuários, turísticos e de conservação ambiental. Revista Brasileira de Ecoturismo, 6 (2), 400-413. Retrieved from http://www.sbecotur.org.br/rbecotur/ seer/index.php/ecoturismo/article/view/394/465

Pedreira, B. C. C. G., Fidalgo, E. C. C., Araújo, F. C., Jesus, I. R. D., \& Pocidonio, E.A.L. (2014a). Aliança entre agroturismo e agricultura familiar em Cachoeiras de Macacu: potencialidades e limitações. Documentos, (172). Retrieved from http://ainfo.cnptia.embrapa.br/digital/bitstream/item/145020/1/ Doc-172-Alianca-Agroturismo.pdf

Pedreira, B. C. C. G., Fidalgo, E. C. C., Carneiro, M. J. T. (2014b). Desenvolvimento do agroturismo em Cachoeiras de Macacu, RJ: Subsídios ao planejamento da atividade agroturística associada à produção agropecuária de base familiar. Boletim de Pesquisa e Desenvolvimento, (244). Retrieved from http://ainfo. cnptia.embrapa.br/digital/bitstream/item/142637/1/BPD-244-Desenv-Agroturismo-Cach-Macacu.pdf

Portuguez, A. P. (2002). Agroturismo e desenvolvimento regional. São Paulo: Hucitec.

Programa das Nações Unidas para o Desenvolvimento [PNUD], Instituto de Pesquisa Econômica Aplicada [Ipea] \& Fundação João Pinheiro [FJP] (2013). Atlas do Desenvolvimento Humano no Brasil. Brasília: PNUD, Ipea, FJP. Retrieved from http://atlasbrasil.org.br/2013/pt/o_atlas/o_atlas /

Pulido, J. I. \& Cárdenas, P. J. (2011). El turismo rural en España: Orientaciones estratégicas para uma tipología aún en desarrollo. Boletín de la Asociación de Geógrafos Españoles, (56), 155-176. Retrieved from https://dialnet.unirioja.es/servlet/articulo? codigo=3722434

Rejowski, M. (1999). Formação de recursos humanos para o turismo rural. In C. G. S. Oliveira (Ed.), Anais I Congresso Brasileiro de Turismo Rural: turismo no espaço rural brasileiro (pp. 57-71). Piracicaba: FEALQ.

Rincón, A., Santos, D. \& Villegas, L. (2015) La sustentabilidad ambiental en las unidades agroturísticas cafeteras en el departamento del Quindío. Contexto, 4, 50-58. https://doi.org/10.18634/ctxj.4v.1i.417

Rodrigues, I. S. (2000). As abordagens tipológicas envolvendo o turismo no espaço rural. In II Anais do Congresso Brasileiro de Turismo Rural. Piracicaba, 129-135.

Rodrigues, A. B. (2001). Turismo rural no Brasil: ensaio de uma tipologia. In: Adyr Balastreri Rodrigues (Org.). Turismo rural: práticas e perspectivas. São Paulo: Contexto.

Salles, M. M. G. (2003). Inventário turístico no meio rural. Campinas: Editora Alínea. 
Santos, R. F. (2004). Planejamento ambiental: teoria e prática. São Paulo: Oficina de Textos.

Serviço Brasileiro de Apoio às Micro e Pequenas Empresas-RJ [SEBRAE-RJ]. (2011). Informações socioeconômicas do município de Cachoeiras de Macacu. Rio de Janeiro: SEBRAE-RJ.

Stange, A., Weber, A. C., Caiado, A. G. C., Costa, A. N., Perota, C., Uliana, D. A., ... y Carnielli, P. (2005). Impactos sobre o turismo no Espirito Santo. In Orlando Caliman (Coord.). Impactos sobre o turismo no Espirito Santo. Vitória: SEBRAE-ES.

Streifeneder, T. (2016). Agriculture first: assessing European policies and scientific typologies to define authentic agritourism and differentiate it from countryside tourism. Tourism Management Perspectives, 20, 251-264. https://doi.org/10.1016/j.tmp.2016.10.003

Szmulewicz, P. E., Gutiérrez, C. V. \& Winkler, K. Ch. (2012) Asociatividad y agroturismo: Evaluación de las habilidades asociativas en redes de agroturismo del sur de Chile. Estudios y Perspectivas en Turismo, 21, 1013-1034.

Sznajder, M.; Przezborska, L.; Scrimgeour, F. (2009). Agritourism. Cambridge, MA: Cabi Publishing. http://dx.doi.org/10.1079/9781845934828.0000

Tomazzoni, E. L., Bock, I. A., Simon, S. (2012). Caminhos da Colônia: turismo rural na Serra Gaúcha-RS, Brasil. Rosa dos Ventos, 4(2), 250-262. Retrieved from http://www.redalyc.org/pdf/4735/473547089010.pdf

Toresan, L.; Mattei, L.; Guzzatti, T.C. (2002). Estudo do potencial do agroturismo em Santa Catarina: impactos e potencialidades para a agricultura familiar. Florianópolis: Instituto Cepa.

Tulik, O. (2003). Turismo Rural. São Paulo: Aleph.

Turnes, V. A. \& Guzzati, T. C. (2015). Turismo rural na agricultura familiar: conceitos e práticas. Florianópolis: Imaginar o Brasil. Retrieved from http://docplayer.com.br/25428662-Turismo-ruralna-agricultura-c-once-ito-s.html

Universidade Federal Fluminense. (2004). Projeto Macacu. Rio de Janeiro: Universidade Federal Fluminense. Coordenadoria de Usos e Potencialidades Agrícolas. v.1. Retrieved from http://www.uff. br/projetomacacu/relatorios/volume 1 cpa.pdf

Wilkinson, J.; Camphora, A. L.; Pinheiro, F.D.; Ranauro, M. (2011). Perfil rural/agrícola de municípios diretamente influenciados pelo Comperj - Diagnóstico de tendências. Rio de Janeiro: Rede de Desenvolvimento, Ensino e Sociedade.

Wilkinson, J.; Pereira, P. R. F; Funcke, A. L.; Camphora, A. L.; Latini, J. L.; Lopane, A. R. M.; Pedreira, B. C. C. G.; Fidalgo, E. C. C.; Prado, R. B. (2012). Caracterização socioeconômica das bacias hidrográficas dos rios Guapi-Macacu e Caceribu. Documentos, (194). Retrieved from https://ainfo.cnptia.embrapa. br/digital/bitstream/item/107015/1/DOC-149-Socioeconomia-Guapi-Macacu.pdf 